Pesq. Vet. Bras. 37(1):31-35, janeiro 2017

DOI: $10.1590 /$ S0100-736X2017000100005

\title{
A simple and fast sampling method for chemical analyses and densitometry of bones through rib biopsies in cattle ${ }^{1}$
}

\author{
Pedro Malafaia ${ }^{2 *}$, Yury T.G. Salcedo ${ }^{3}$, Ricardo A.R. Uscategui ${ }^{4}$, Vinícius C. Souza ${ }^{3}$, \\ Diogo Fleury A. Costa ${ }^{5}$ and Telma T. Berchielli ${ }^{3}$
}

\begin{abstract}
Malafaia P., Salcedo Y.T.G., Uscategui R.A.R., Souza V.C., Costa D.F.A. \& Berchielli T.T. 2017. A simple and fast sampling method for chemical analyses and densitometry of bones through rib biopsies in cattle. Pesquisa Veterinária Brasileira 37(1):31-35. Departamento de Nutrição Animal e Pastagem, Instituto de Zootecnia, Universidade Federal Rural do Rio de Janeiro, Campus de Seropédica, BR 465-Km 7, Seropédica, RJ 23890-000, Brazil. E-mail: malafaia_ufrrj@yahoo.com.br

We developed and evaluated a fast and simple method to obtain suitable bone samples for densitometry and chemical analysis through biopsies of the 12 th rib of cattle. The postoperative recovery, dry matter intake (DMI) and average daily weight gain (ADG) was evaluated in 36 Nellore steers, nine of which were randomly selected for the control group and 27 others were rib biopsied. Every 30 days, rib biopsy was performed in nine steers, using a corded-electric pistol-grip drill coupled with a hole saw of a $3 \mathrm{~mm}$ diameter pilot drill bit. This rib biopsy technique provided a suitable sample obtained in a fast way and allowed the surgeon to work alone with the animal slightly sedated and restrained in the crush. Dry matter intake (DMI) was not affected in biopsied animals. At the end of the experimental period (116 days) the average daily weight gain (ADG) was similar in the steers biopsied or not. The described method provided rib samples from cattle suitable for densitometry and chemical analysis of bone tissue without effects on health and performance. This information could greatly increase the accuracy for the diagnosis of phosphorus deficiency in cattle raised on pasture and allow the evaluation of bone metabolism in experimental animals.
\end{abstract}

INDEX TERMS: Sampling method, chemical analysis, bone densitometry, rib biopsy, cattle, bone mineral density, Bos indicus, mineral deficiency, phosphorus.

RESUMO.- [Uma técnica simples e rápida de amostrar costelas para análises químicas e densitométricas por meio de biópsias em bovinos.] No presente estudo foi desenvolvida uma técnica para se obter, de forma rápida e simples, amostras da $12^{\text {a }}$ costela bovina por meio de biópsias. Avaliou-se a recuperação pós-operatória (durante 15 dias), o consumo de matéria seca (CMS) e

\footnotetext{
${ }^{1}$ Received on September 24, 2016.

Accepted for publication on October 28, 2016.

${ }^{2}$ Departamento de Nutrição Animal e Pastagem, Universidade Federal Rural do Rio de Janeiro (UFRRJ), Seropédica, RJ 23890-000, Brazil. *Corresponding author: malafaia_ufrrj@yahoo.com.br

${ }^{3}$ Departamento de Zootecnia, Universidade Estadual Paulista (Unesp), Campus Jaboticabal, Rodovia Professor Paulo Donato Castellane Km 5, Jaboticabal, SP 14884-900, Brazil.

${ }^{4}$ Departamento de Medicina Veterinária Preventiva e Reprodução Animal, Unesp, Campus Jaboticabal, Rodovia Professor Paulo Donato Castellane Km 5, Jaboticabal, SP 14884-900, Brazil.

${ }^{5}$ Departamento de Ciências Agrárias, Centro Universitário Octavio Bastos, Campus II, São João da Boa Vista, SP 13874-149, Brazil.
}

o ganho de peso diário (GMD) de 36 novilhos Nelores, sendo nove animais controles e 27 submetidos à biópsia. A cada 30 dias biópsias de costelas foram realizadas em nove animais, usando uma furadeira elétrica acoplada a uma serra-copo com uma broca-guia de $3 \mathrm{~mm}$ de diâmetro. Esta técnica de biópsia permitiu obter amostras ósseas de forma rápida, com o cirurgião operando sozinho e com os animais levemente sedados e em estação. Ao término do experimento (116 dias) o CMS e o GMD não foram afetados pelo procedimento cirúrgico. As amostras obtidas foram adequadas para exames radiográficos e subsequentes análises químicas. 0 conjunto de informações adquiridas com a técnica de biópsia de costelas permite aumentar a exatidão no diagnóstico da deficiência de fósforo em bovinos criados em pastagens e também realizar estudos sobre metabolismo ósseo em animais experimentais.

TERMOS DE INDEXAÇ̃̃O: Análise química, densitometria, biópsia de costela, bovinos, fósforo, Nelore. 


\section{INTRODUCTION}

Bone biopsy is an important surgical procedure used in physiological and pathological studies of bone tissue (Chavassieux et al. 2001). Despite its use in histopathological studies, this technique can be used for other purposes, such as in studies related to calcium (Ca), phosphorus (P) and magnesium (Mg) metabolisms (Little 1972, Beighle et al. 1993). According to Riet-Correa \& Timm (2007) and Radostits et al. (2007), P content in bone ash is still considered the most accurate indicator of phosphorus status of cattle. In this context, the rib biopsy is a very useful technique to confirm the diagnosis of $\mathrm{P}$ deficiency in cattle raised on pasture, as well as in experiments which evaluate the dynamics of bone tissue; because it allows the assessment of bone mineral content in cattle, by obtaining a greater number of bone samples to be used for evaluations involving radiographic images and histopathological studies. Another advantage is the possibility to biopsy the same animal over time during experimental periods (Little 1972, Almeida \& Brum 1980, Beighle et al. 1993).

Among the different procedures to obtain rib samples is the use of trephines (Little 1972, Read et al. 1986) and pliers (Almeida \& Brum 1980). However, these methods provide only very small samples, with irregular surfaces and in varying sizes, which serve only for chemical and/ or histopathological analyses (Judkins et al. 1985, Beighle et al. 1993), and are not suitable for image exams. On the other hand, invasive procedures are necessary to obtain larger amounts of rib for diagnostic imaging as performed by Call et al. (1978) and Wu et al. (2001), who withdrew a whole rib or fragments of about $20 \mathrm{~cm}$ from cattle. Large invasive methods can cause pain, stress, immune suppression, affect DMI and productive performance, and thus may compromise assessments of animals used in experiments on which these variables are evaluated. Therefore, there is a need to evaluate to what extent surgical sampling of bone tissue compromises cattle health and performance. Almeida \& Brum (1980) evaluated cattle subjected to rib biopsy during the two days post-operation, and reported no complication. However, those authors did not evaluate the recovery of the animals or the efficacy of bone samples for X-ray examination.
In this study we proposed and evaluated a technique to obtain bone samples by means of biopsy of the 12th rib and the postoperative recovery/evolution, DMI and ADG of Nellore steers in an experimental feedlot.

\section{MATERIALS AND METHODS}

The protocol used in this experiment was in accordance with the Brazilian College of Animal Experimentation Guidelines (COBEA - Colégio Brasileiro de Experimentação Animal) and was approved by the Ethics, Bioethics, and Animal Welfare Committee of São Paulo State University (Unesp), Jaboticabal Campus, under protocol 7741/14.

Thirty-six 30 month-old Nellore steers were used. Animals' initial weight ( $296 \pm 25 \mathrm{~kg}$ body weight (BW)) was obtained after a 16 hours of feed and water curfew. The steers were randomly divided into 2 groups (CG, control group and BG, biopsied group). During the experiment, the steers were kept in individual pens $\left(12 \mathrm{~m}^{2}\right)$ with access to a covered bunk area and a water trough.

The steers were adapted for 21 days to facilities and diets using increased concentrate levels. After the adaptation phase, the total mixed ration (DM basis) consisted of $200 \mathrm{~g} / \mathrm{kg}$ sugarcane bagasse and $800 \mathrm{~g} / \mathrm{kg}$ concentrate, which was formulated to have $130 \mathrm{~g} / \mathrm{kg} \mathrm{CP}$ and reach an average daily gain of $1.25 \mathrm{~kg}$, based on nutritional AFRC (1993) recommendations. The concentrate had $474.0 \mathrm{~g} / \mathrm{kg}$ ground corn, $88.0 \mathrm{~g} / \mathrm{kg}$ soybean meal, $216.0 \mathrm{~g} / \mathrm{kg}$ citrus pulp, $8.0 \mathrm{~g} / \mathrm{kg}$ urea and $4.0 \mathrm{~g} / \mathrm{kg}$ commercial mineral mix. The diet was provided twice a day, at 6:00h and 16:00h, allowing about 5\% residues. The experiment lasted 116 days.

Three groups of nine steers were biopsied on days 30,60 and 90 , whereas nine steers were used as controls. Before each biopsy procedure, the animals were fasted for 16 hours in order to reduce the volume occupied by ruminal digesta and avoid possible complications during the surgery performed on the 12th left rib. Immediately before surgery, the animals were restrained in the crush and were dosed with $0.05 \mathrm{mg} / \mathrm{kg}$ (i.m.) of xylazine to ensure a light sedation. All surgical procedures were performed with the steers in standing position. The surgical area was delimited at the proximal third of the 12th left rib (about $8 \mathrm{~cm}$ ventral to the line of the lumbar transverse process), between the cranial and caudal border (Fig.1). The surgical site was thoroughly washed with water and then applied a neutral detergent to carry out the trichotomy. The area was then cleansed and desinfected again with four applications of $2 \%$ chlorhexidine and $70 \%$ alcohol solution. Subsequently, a local anaesthetic blo-

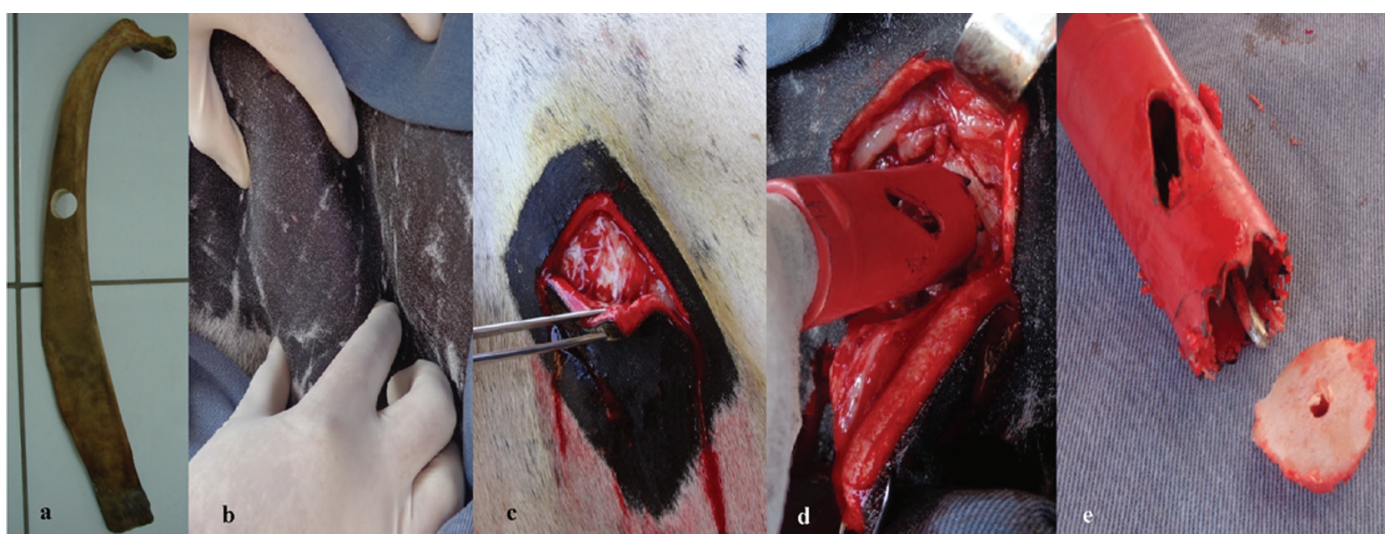

Fig.1. From left to right: Sampling site on ribs $(a, b)$, vertical and transverse incision (c) , pilot drill bit positioned at the central part of the rib (d), pilot drill bit cut in its base to result about $5 \mathrm{~mm}$ of projection out of the $25 \mathrm{~mm}$ diameter hole saw and a circular rib sample obtained after biopsy (e). 

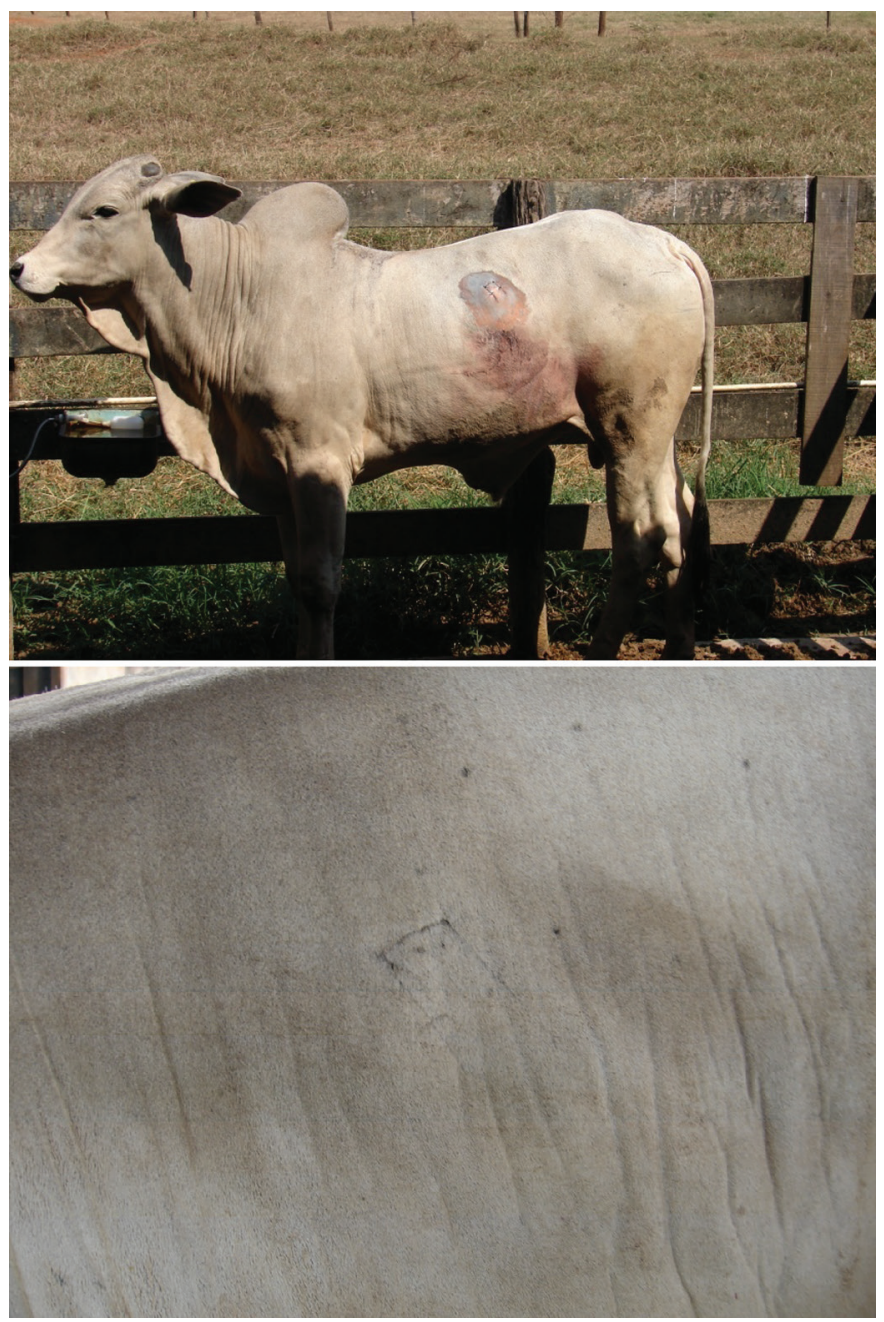

Fig.2. Steer 15 minutes and 21 days after rib biopsy.
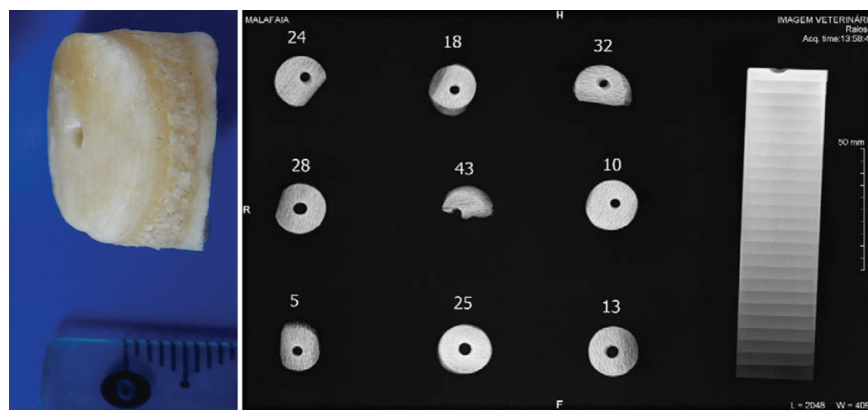

Fig.3. From left to right. Outer, medullary cavity (diploe) and inner cortical layer of a rib biopsy. Radiographic images obtained from rib samples (numbers correspond to the biopsied animals on August 22, 2014).

ckade was made in the ventral branch of the intercostal nerve of the $12 \mathrm{th}$ rib. On the exact site of the surgical wound, $10 \mathrm{~mL}$ $2 \%$ lidocaine hydrochloride was deeply infiltrated half into the cranial border and half into the caudal border of the rib. After onset of the local anesthetic, two vertical incisions of about $8 \mathrm{~cm}$ length were performed, parallel to the cranial and caudal border of the 12 th rib, and a transverse incision was made at the top to form a rectangular surgical wound exactly over the lateral side of the 12th left rib (Fig.1c). After hemostasis, a blunt dissection of the subcutaneous tissue was made and the muscles cutaneus trunci and obliquus externus abdominalis were cut with a scalpel. Any soft tissue was removed with a forceps to give access to the external surface of the rib. A $25 \mathrm{~mm}$ diameter hole saw, coupled with a $3 \mathrm{~mm}$ diameter pilot drill bit, was used to obtain a circular rib sample (Fig.1e). The pilot drill bit was cut at its base to result about $5 \mathrm{~mm}$ of projection out the hole saw (Fig.1e). The kit was inserted and properly tightened to the chuck of a corded-electric pistol grip drill, with variable speed control, and was positioned in the center of the rib, and then submitted to a slower speed at first. Positioning the pilot drill bit in the central part of the rib prevented breakage of sample, resulting in too light rib sample (see steer 43; Table 2 and Fig.2). The correct procedure must be as follows: After the pilot drill bit pierces the periosteum and reaches the diploe of the rib, the speed of the pistol-grip drill can be increased and the hole saw begins to cut the rib until complete extraction of the circular bone sample (Fig.1e). At this stage the surgeon has to be careful and avoid the hole saw going to deeply inside the abdominal cavity; this is can be done by reducing the speed of the pistol grip drill once again.

In the current experiment, after the extraction of the rib samples, any soft tissues and periosteum was removed. Before suturing the surgical wound, the muscles and the remaining subcutaneous tissue were placed over the hole made in the rib and the skin was repositioned in its original position. The suture procedure was performed in a simple interrupted pattern with nylon \# 2. The rib samples were stored in clean plastic bags, previously identified and frozen at $-20^{\circ} \mathrm{C}$ for further evaluation of bone mineral density and chemical analysis of minerals in the bone ash.

Postoperative treatment consisted of intramuscular injection of penicillin (sodium, procaine and benzathine $12000 \mathrm{IU} /$ $\mathrm{kg})$, streptomycin $(5 \mathrm{mg} / \mathrm{kg})$ and piroxicam $(0.5 \mathrm{mg} / \mathrm{kg})$. This treatment was repeated $48 \mathrm{~h}$ after the surgery. Once a day, the closed wound was sprayed with a spray solution mixture containing silver sulfadiazine $(0.1 \mathrm{~g})$, aluminium $(5.0 \mathrm{~g})$ and cypermethrin (0.4g) per $100 \mathrm{~g}$.

During 15 days, the animals were evaluated daily for clinical status, DMI, expression of pain signals (Fitzpatrick et al. 2006) and wound healing. After this period, the knots were removed.

For the assessment of bone mineral density (BMD) a digital X-ray machine, model OEC 9900 Elite Series GE OEC Medical Systems, calibrated, with focus-film distance of $90 \mathrm{~cm}$, adjusted to 60 $\mathrm{kVp}, 10 \mathrm{~mA}$, and 0.1 seconds of exposure time was used to take radiographs of all 12th rib samples obtained by biopsies, with a 25step (1mm height) aluminum step wedge. The digital radiographs were saved as JPG format. For the estimation of BMD we use the histogram tool of Corel Photo Paint X4 software.

At the end of experimental period, the steers were weighed as per described curfew protocol, to obtain the final ADG. The experimental design was randomized blocks (periods) with repeated measurements over time (days). Statistical analyses were performed using software $\mathrm{R}^{\circledR}$ (R Foundation for Statistical Computing, Viena, Austria). The variables were evaluated for homoscedasticity of variance and normality of the data; after these assumptions had been met, analysis of variance was performed. When the difference between treatments was significant, the means were compared by Tukey test. The significance level adopted for all tests was $5 \%$ of error probability.

The statistical model used was:

$$
y_{i j k}=\mu+t_{i}+b_{j(i)}+t_{k}+e_{i j}
$$

where: $y_{i j}=$ observation of animal $j$ subjected to biopsy $I$ on block $k ; \mu_{x}=$ the overall mean; $t_{i}=$ the effect of biopsy $i ; b_{j(i)}=j$ block, $i$ biopsy; $t_{k}=$ effect of the $k^{\text {th }}$ time after surgery; $e_{i j}=$ the residual experimental error. 


\section{RESULTS}

In general, after onset of local anesthetic, the surgical procedure was completed in approximately 10 to 15 minutes. Throughout the procedure, the steers remained calm and showed no pain reaction, indicating that after a light sedation, the local anesthetic blockade of intercostal nerve of the 12th rib was effective for suitable analgesia. From the 27 steers submitted to rib biopsies, complications were recorded only in two of them, with inflammation of the surgical area and/or wound infection. In those cases, the cattle was treated with systemic anti-inflammatory and antibiotics. The surgical protocol proposed allowed full recovery of all animals within 15 to 21 days (Fig.2).

After the surgical procedure, the animals were returned to their pens (Fig.2), with access to feed. The feeding activity took place after a few minutes, followed by apparently normal rumination process. The DMI of the biopsied animals (BG) was significantly lower between the first and the ninth postoperative days; but on the tenth day, the difference was not significant (Table 1). At the end of the experiment, ADG was similar ( $p=0.395)$ between the control group $(1.19 \pm 0.32 \mathrm{~kg} / \mathrm{d})$ and animals subjected to rib biop$\operatorname{sies}(1.13 \pm 0,30 \mathrm{~kg} / \mathrm{d})$.

As the procedure was being carried out, there was a considerable increase in experience, as demonstrated by an increase in average weights of the rib samples (Table 2).

Table 1. Daily dry matter intake of Nellore steers submitted (BG) or not (CG) to rib biopsies

\begin{tabular}{cccc}
\hline \multicolumn{4}{c}{ Dry matter intake (kg/day) } \\
\hline Day & BG & CG & P-value \\
\hline 1 & $7.28 \pm 1.53$ & $7.95 \pm 1.85$ & 0.013 \\
2 & $7.39 \pm 1.68$ & $8.51 \pm 1.16$ & 0.003 \\
3 & $7.19 \pm 1.49$ & $8.24 \pm 1.53$ & 0.013 \\
4 & $7.21 \pm 1.69$ & $8.33 \pm 1.45$ & 0.012 \\
5 & $6.99 \pm 1.37$ & $8.28 \pm 1.47$ & 0.001 \\
6 & $7.05 \pm 1.42$ & $8.36 \pm 1.46$ & 0.002 \\
7 & $7.14 \pm 1.43$ & $8.18 \pm 1.41$ & 0.009 \\
8 & $7.29 \pm 1.38$ & $8.38 \pm 1.39$ & 0.006 \\
9 & $7.55 \pm 1.41$ & $8.34 \pm 1.28$ & 0.039 \\
10 & $7.47 \pm 1.54$ & $8.06 \pm 1.31$ & 0.135 \\
11 & $7.98 \pm 1.41$ & $8.56 \pm 1.41$ & 0.139 \\
12 & $7.94 \pm 1.46$ & $8.65 \pm 1.45$ & 0.076 \\
13 & $8.02 \pm 1.46$ & $8.69 \pm 1.47$ & 0.092 \\
14 & $8.14 \pm 1.46$ & $8.41 \pm 1.49$ & 0.478 \\
15 & $8.18 \pm 1.49$ & $8.76 \pm 1.69$ & 0.154
\end{tabular}

Table 2. Average and standard deviation of rib samples

\begin{tabular}{|c|c|c|c|c|c|}
\hline \multicolumn{6}{|c|}{ Date } \\
\hline \multicolumn{2}{|c|}{ August 22, 2014} & \multicolumn{2}{|c|}{ September 24,2014} & \multicolumn{2}{|c|}{ October 26, 2014} \\
\hline Animal & Weight (g) & Animal & Weight (g) & Animal & Weight (g) \\
\hline 24 & 2.638 & 20 & 2.950 & 2 & 4.808 \\
\hline 28 & 2.731 & 40 & 3.281 & 49 & 3.911 \\
\hline 5 & 1.866 & 46 & 2.776 & 41 & 3.088 \\
\hline 18 & 2.515 & 37 & 3.574 & 44 & 2.226 \\
\hline 43 & 1.204 & 27 & 2.971 & 33 & 3.656 \\
\hline 25 & 3.777 & 9 & 2.452 & 39 & 3.493 \\
\hline 32 & 2.497 & 30 & 2.766 & 42 & 3.886 \\
\hline 10 & 3.480 & 15 & 3.321 & 45 & 2.689 \\
\hline 13 & 2.372 & 14 & 2.965 & 36 & 4.360 \\
\hline Average (g) & 2.565 & Average (g) & 3.006 & Average(g) & 3.414 \\
\hline SD & 0.769 & SD & 0.340 & SD & 0.704 \\
\hline
\end{tabular}

All bone samples were adequate to carry out the bone densitometry exams (Fig.3).

\section{DISCUSSION}

Based on the results, we suggest that the rib biopsy procedure described here can be used in studies to assess the composition and bone mineral density in cattle without compromising DMI and performance, and especially in studies where the sampling is carried out over time. The described technique proved to be a safe and simple procedure that can be performed very fast with the animals under light sedation and in standing position.

The effect of more invasive surgical procedures on DMI, ADG, postoperative and clinical evolution has not been evaluated or described in cattle (Call et al. 1978, Almeida \& Brum 1980, Wu et al. 2001, Bomjardim et al. 2015).

Bomjardim et al. (2015) used a rib biopsy technique performed in cattle deeply sedated and placed into left lateral recumbency. Due to bloat risks, this procedure is believed to be inappropriate for experiments with feedlot cattle where high grain diets are used. In our study, after the surgical procedure, the animals walked slowly back to their pens, and within a few minutes were eating and drinking. Therefore, we recommend this procedure for situations where cattle are submitted to high grain diets, as used here.

Despite the large diameter of the hole saw $(25 \mathrm{~mm})$, no animal had any broken bones during the procedures. Having a broken rib could implicate in various problems, for example, price downgrade at sale for slaughter.

The classical method described by Little (1972) is widely used, and involves extracting only the outer cortical rib layer. This one-layer rib sample is not useful for X-ray examinations and serves only for histopathological studies or chemical analysis of minerals. Our method removes the outer, medullary cavity (diploe) and inner cortical layer. The sample obtained this way is representative to rib architecture and it is suitable to X-ray examination. Also, the circular shape with a wide area made the rib samples suitable to perform a comparative bone densitometry analysis along with a 25 -step ( $1 \mathrm{~mm}$ height) aluminum wedge (Fig.3).

Therefore, the technique proposed in this paper has proved to be suitable for obtaining samples first to be used for radiographs, and second for histopathological exams and analysis of $\mathrm{Ca}, \mathrm{P}$ and $\mathrm{Mg}$ in bone. This method may increase the accuracy of the diagnosis of P deficiency in cattle raised on pasture, and allow the evaluation of bone metabolism in experimental animals.

\section{CONCLUSIONS}

The method proposed in this paper was proven to be a simple and fast technique that provided rib samples suitable for bone densitometry and chemical analysis, with no deleterious effects on health, feed intake or performance of cattle.

The adoption of this methodology may help to improve the diagnosis of P deficiency in cattle raised on pasture and 
could also be used for evaluation of bone metabolism in experimental animals.

Acknowledgements.- The authors wish to thank Prof. Luciano Alonso (UFRRJ, IV) for valuable suggestions and Dr. Jarud Muller (Department of Agriculture and Fisheries, Queensland, Australia) for reviewing the English version of the manuscript.

\section{REFERENCES}

AFRC 1993. Energy and Protein Requirements of Ruminants. Agricultural and Food Research Council. CAB International, Cambridge University Press, Cambridge. 159p.

Almeida I.L. \& Brum P.A.R. 1980. Técnica em biópsia óssea em bovinos para estudo de minerais. Pesq. Agropec. Bras. 15:121-122.

Beighle D.E., Boyazoglu P.A. \& Hemken R.W.1993. Use of bovine rib bone in serial sampling for mineral analysis. J. Dairy Sci. 76:1047-1052.

Bomjardim H.A., Oliveira C.M.C., Silveira J.A., Silva N.S., Duarte M.D., Faial K.C.F., Brito M.F. \& Barbosa J.D. 2015. Deficiências minerais em vacas em lactação da bacia leiteira do munícipio de Rondon do Pará, Estado do Pará. Pesq. Vet. Bras. 35:409-416.

Call J.W., Butcher J.E., Blake J.T., Smart R.A. \& Shupe J.L. 1978. Phosphorus influence on growth and reproduction of beef cattle. J. Anim. Sci. 47:216225.
Chavassieux P., Arlot M. \& Meunier P.J. 2001. Clinical use of bone biopsy, p.501-509. In: Ibid. (Eds), Osteoporosis. Vol.2. 2nd ed. Academic Press, San Diego, CA.

Fitzpatrick J., Scott M. \& Nolan A. 2006. Assessment of pain and welfare in sheep. Small Rum. Res. 62:55-61.

Judkins M.B., Wallace J.D., Parker E.E. \& Wright J.D. 1985. Performance and phosphorus status of range cows with and without phosphorus supplementation. J. Range Management 38:139-143.

Little D.A. 1972. Bone biopsy in cattle and sheep for studies of phosphorus status. Aust. Vet. J. 48:668-670.

Radostits O.M., Gay C.C., Hinchcliff K.W. \& Constable P.D. 2007. Diseases associated with nutritional deficiencies, p.321-56. In: Ibid. (Eds), Veterinary Medicine: a textbook of the diseases of cattle, horses, sheep, pigs, and goats. 10th ed. W.B. Saunders, Philadelphia. 1761p.

Read M.V.P., Engels E.A.N. \& Smith W.A. 1986. Phosphorus and the grazing ruminants. 4. Blood and faecal grab samples as indicators of the P status of cattle. South Afr. J. Anim. Sci. 16:18-22.

Riet-Correa F. \& Timm C.D. 2007. Deficiência de fósforo, p.248-257. In: RietCorrea F., Schild A.L., Lemos R.A.A. \& Borges J.R.J. (Eds), Doenças de Ruminantes e Equídeos. Vol.2. Pallotti, Santa Maria.

Wu Z., Satter D., Blohowiak A.J., Stauffacher R.J. \& Wilson J.H. 2001. Milk production, estimated Phosphorus excretion, and bone characteristics of dairy cows fed different amounts of phosphorus for two or three years. J. Dairy Sci. 84:1738-1748. 